\title{
PERANCANGAN PEN+ MENGGUNAKAN METODE YII FRAMEWORK PADA PERGURUAN TINGGI RAHARJA
}

\author{
Diah Aryani ${ }^{1}$ \\ Qurotul Aini ${ }^{2}$ \\ Tasya Novelia ${ }^{3}$ \\ Dosen STMIK Raharja ${ }^{1,2}$ \\ STMIK Raharja Jurusan Sistem Informasi ${ }^{1}$ \\ Jl. Jendral Sudirman No. 40, Modernland, Tangerang ${ }^{1,2,3}$ \\ Email:diah.aryani@raharja.info', aini@raharja.info ${ }^{2}$,tasya@raharja.info ${ }^{3}$
}

\begin{abstract}
ABSTRAK
Sistem Penilaian online merupakan bagian dari sistem informasi pendidikan jarak jauh melalui media teknologi elektronik internet. Peranan komputer sangatlah penting dalam kegiatan administrasi sekolah terutama dalam kegiatan pengolahan nilai mahasiswa. Meskipun sistem yang ada sudah terkomputerisasi, akan tetapi masih ada kendala-kendala yang sering ditemui dalam proses pengolahan nilai seperti keterlamabatan dosen dalam mengumpulkan nilai, membutuhkan waktu yang lama dalam mengolah nilai dan proses memasukkan nilai ke komputer dibebankan kepada bagian RPU. Berdasarkan kekurangan-kekurangan diatas, maka dibuatlah sistem informasi nilai mahasiswa berbasis web. Sistem ini dibuat dengan menggunakan aplikasi web berbasis PHP. Pembangunan sistem informasi ini membantu memudahkan dosen mata kuliah dalam mengisi nilai karena dapat dilakukan secara online melalui website, sehingga pengolahan nilai bisa lebih efektif dan efisian. Siswa juga dapat mengakses nilai melalui website. Selain efektif banyak juga kemudahan yang didapat dalam sistem PEN+ ini, yaitu mengiri waktu untuk kinerja penilaian sehingga waktunya dapat dimanfaatkan untuk hal-hal yang berguna lainnya, mengurangi beban divisi RPU, tidak lagi menggunakan sistem yang repot serta dosen yang bersangkutan dalam proses penilaian harus datang kekampus. Maka dengan metode Penilaian Online ini yang bertujuan untuk meningkatkan mutu kualitas dosen maupun mahasiswa manajemen perguruan tinggi.
\end{abstract}

Kata Kunci : PEN+, Wah gampang Kan, Penplus, Penilaian Online, Penilaian Plus

\begin{abstract}
Online assessment system is part of a system of educational information remotely through electronic media internet technology. The role of computers is very important in the administration of schools, especially in processing activities, student grades. Although the existing system has been computerized, but there are still obstacles that are often encountered in the processing of such value keterlamabatan lecturer in collecting the value, takes a long time in processing the value and process of inserting value into the computer charged to part RPU.Berdasarkan shortcomings above, then made the information system web-based student grades. The system is built using PHP based web applications. Development of information system helps facilitate the lecturer in charge value because it can be done online through the website, so that the processing value can be more effective and fuel-efficient. Students can also access the value through the website. In addition to effectively many convenience gained in the system PEN + this, that go to the left time for performance assessment so that the time can be used for things other useful, reducing the burden of division RPU, no longer uses the system to bother with the lecturer in the assessment process must come to campus. So with the Online Assessment method that aims to increase the quality of faculty and students of the university management.
\end{abstract}

Keywords: PEN +, Wah easy Kan, Penplus, Online Assessment, Assessment Plus 


\section{PENDAHULUAN}

Metode Penilaian merupakan bagian yang tidak dapat dipisahkan dalam suatu proses belajar-mengajar. Penilaian adalah koleksi dari informasi yang valid, reliabel, dan bertujuan untuk meningkatkan penampilan. Penilaian memerlukan informasi yang baik dan informasi yang baik itu harus valid dan reliabel. Penilaian digunakan sebagai usaha untuk melihat keberhasilan proses belajar mengajar yang ditunjukkan dalam bentuk nilai dan juga digunakan sebagai penilaian terhadap usaha dalam rangka perbaikan suatu penampilan. Jadi dalam penilaian harus dilakukan secara adil, dan harus dihubungkan dengan tujuan. Langkah-langkah penting dalam proses penilaian mencakup tujuan, menuangkan kembali tujuan dalam bagian perilaku, berhasil dalam target dan kriteria, mengumpulkan baseline data, mencapai tujuan melalui strategi khusus dan pengukuran reguler, memelihara sekaligus mengembangkan keterampilan, dan mengontrol terhadap pengajaran. teknologi yang berkembang dengan pesat dan menjadi kebutuhan yang sangat penting membuat dunia pendidikan memerlukan media untuk penilaian belajar mengajar, yang berdampak pada semua aspek yang berhubungan dengan informasi salah satu perkembangan teknologi adalah $\mathrm{PEN}+$, maka dari itu untuk mencanggihkan suatu sistem penilaian dengan adanya Project $\mathrm{PEN}+$, memudahkan dosen dalam melakukan penilaian terhadap mahasiswa, Dimana sistem penilaian yang canggih ini dapat membantu meringakan, waktu dan kertas untuk sistem penilaian .

Metode Penilaian, dimana PEN+ sebagai media utama, namun terintegrasi juga dengan 9 (sembilan) FIR IT lainnya. Dikarenakan untuk menggunakan PEN+, dibutuhkan pendaftaran (register) melalui SISPLUS menggunakan email Rinfo. Rinfo (Email Rahaja.Info) adalah layanan komunikasi email yang disediakan oleh Perguruan Tinggi Raharja untuk semua Pribadi Raharja, alat komunikasi utama dan paling vital untuk para Pribadi Raharja.

Dengan media penilaian untuk kegiatan proses belajar mengajar, sebuah wadah penilaian menggunakan forum cukup efektif dan sangat baik untuk menunjang proses penilaian dan penilaian menjadi efektif untuk mahasiswa iLearning dan Reguler yang proses pembelajarannya menggunakan device yaitu $i P a d$ maupun pembelajaran reguler .

$P E N+$ merupakan sebuah forum aplikasi Yii Framework. Yii Framework merupakan PHP berbasis-komponen, berkinerja tinggi untuk pengembangan aplikasi web berskala-besar. Nama "Yii" merupakan singkatan dari Yes It Is, untuk menjalankan aplikasi Web berbasis Yii, anda memerlukan server Web yang mendukung PHP 5.1.0. Perkembangan forum ini tidak terlepas dari pengaruh perkembangan zaman. Kemajuan teknologi bahkan menuntut forum dikemas secara lebih efisien dan mudah. dibawah ini terdapat logo dari Yii Framework .

Proses Penilaian adalah suatu aktivitas dalam sistem pendidikan. Proses ini merupakan penglihatan objektife maupun subjektif yang dilakukan terhadap mahasiswa serta dipengaruhi oleh hubungan yang ada dalam proses tersebut. Ini menyebabkan metode penilaian mahasiswa juga mempengaruhi metode perkuliahan. Seiring dengan pesatnya perkembangan di dunia telekomunikasi yang ditandai dengan era digital, khususnya di bidang Teknologi Informasi dan Komunikasi (TIK), tentunya proses penilaian juga menuntut adanya penyesuaian atau mengikuti Sistem Manajemen Mutu ISO 9001:2008 dalam penggunaan metode proses penilaian. Adanya realita tersebut, Perguruan Tinggi Raharja yang menerapkan konsep IT dalam proses belajar mengajar jelas memerlukan sarana dan prasarana TIK juga dalam sistem penilaian yang up to date untuk menunjang kegiatan perkuliahan, sehingga dapat menjawab tantangan-tantangan yang ada, khususnya untuk peningkatan kualitas proses penilaian. Salah satu sarana untuk menunjang 
proses pembelajaran adalah penilaian. Karena berbasis teknologi internet sehingga media penilaian PEN+ dapat diakses dari manapun selama tersedia akses ke internet.

Menurut Muhammad Yusuf website tersebut merupakan tempat proses online yang memberikan fasilitas penilaian dikelola tanpa adanya tatap muka langsung di antara pihak-pihak yang terlibat (administrator, dosen, mahasiswa). Kehadiran pihak-pihak yang terlibat diwakili oleh e-mail, sistem, atau melalui notifikasi. Penilaian online yang dibuat dalam penelitian ini menggunakan sebuah paket aplikasi Yii Framework. Sementara itu implementasi dari penilaian online ini dapat digunakan untuk memberikan solusi terhadap permasalahan yang sedang berjalan dalam proses penilaian yang selama ini terbatas pada masalah waktu dan tempat .

\section{PERMASALAHAN}

Dalam penilaian sudah terdapat aturan yang mengharuskan dosen untuk mengoreksi nilai $\mathrm{H}+3$, yaitu 3 hari setelah dilaksanakannya UTS, maupun UAS. Kertas yang diisi harus segera di berikan kepada pihak RPU, namun karena sistem penilaian yang memang sudah terkomputerisasi namun kurang up to date menjadikan aturan penilaian ini sering di langgar, menjadikan pihak rpu memakan waktu lama untuk mengolah data, belum lagi data nilai yang banyak dari 41 dosen, diolah oleh rpu yang stafnya hanya terdapat beberapa staf .

Ternyata penggunaan teknologi sebagai suatu media forum mendapat respons yang positif dari dosen dan mahasiswa.Diskusi yang baik harus direncanakan dan kunci keberhasilannya terletak pada isu atau masalah yang didiskusikan. Hasil merupakan suatu puncak proses pembelajaran, hasil belajar tersebut dapat berupa dampak pembelajaran dan dampak pengiring keduanya merupakan dampak yang saling bermanfaat untuk dosen maupun mahasiswa, hasil tersebut terjadi terutama berkat evaluasi dosen. Berikut ini standar-standar yang dimaksud :

1. Menentukan Grade Penilaian

Setiap mata kuliah dengan memperhatikan karakteristik mahasiswa, karakteristik mata

kuliah, dan kondisi satuan pendidikan melalui rapat dewan pendidik.

2. Mengkoordinisikan

Ujian Tengah Semester, Ujian Akhir Semester, dan Tugas Mandiri.

3. Melaporkan Hasil Ujian.

Hal ini terbukti efektifitas kecanggihan teknologi yang kini telah masuk ke setiap kecil dalam perkembangan teknologi yang sudah ada, media mutakhir ini turut melebarkan sayap kedalam sistem penilaian yang selama ini terbatas oleh ruang dan waktu.

Dari uraian diatas dapat disimpulkan bahwa media sistem penilaian sebelum menggunakan $P E N+$ ternyata memiliki kekurangan yang terjadi pada saat penilaian dahulu, yaitu proses penilaian masih lambat karena walaupun terkomputerisasi tapi masih banyak kekurangan yang menghambat sistem penilaian karena RPU mengolahnya menggunakan Microsoft Excel yang sebelumnya adalah hasil export dari Microsoft Access berupa kolom No,NIM,dan Nama. Setelah selesai input nilai maka akan dilakukan proses print berkas. Berkas yang sudah ready diberikan kembali ke dosen yang bersangkutan, jika ada revisi nilai maka dosen akan coret-coret nilai pada kertas dan tanda tangan di kertas tersebut. RPU kemudian merevisi kembali di Microsoft Excel, file yang ready di import ke Microsoft Access dan di delivery ke divisi REC untuk proses upload database, maka dari itu proses tersebut memakan waktu yang lama. Belum lagi dosen tidak dapat termonitoring jadi mahasiswa dan dosen tidak mengetahui dosen yang mana sajakah yang rajin dan tidak rajin dalam penginputan nilai dengan tepat waktu. 
Yang menjadi kendala saat ini adalah kesulitan para mahasiswa untuk mengetahui hasil nilai secara cepat, maka penilaian yang berteknologi informasi modern saat ini. Akhirnya akan berdampak dan akan mempengaruhi proses implementasi, dan suatu Penilaian Terkomputerisasi yang menghadirkan sebuah Kendala dalam proses dosen untuk menginput nilai dan mahasiswa melihat nilainya, dengan demikian sistem ini sangat berperan penting dalam pengembangan kualitas pelayanan kampus, ini merupakan sebuah sistem penilaian yang terkomputerisasi. Sistem penilaiannya yaitu :

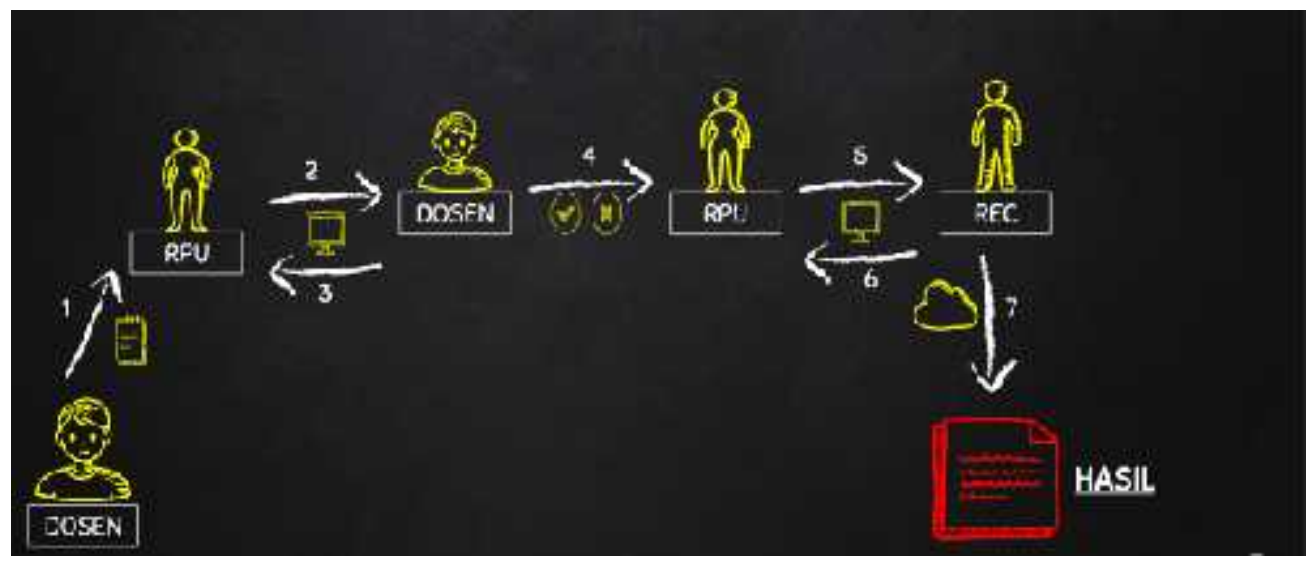

Gambar 1. Gambar sistem penilaian yang terkomputerisasai.

Dari gambar diatas, terdapat sistem penilaian yang terkomputerisasi namun belum online, banyak terjadi kendala seperti saat proses penyerahan nilai sampai dengan pengolahan nilai hingga memperoleh Grading/huruf mutu yang masih terdapat beberapa kendala dengan kekurangan sehingga sistem tersebut belum bisa berjalan dengan maksimal, beberapa kendala lainnya yaitu dosen yang bersangkutan harus datang kekampus untuk menyerahkan data-data nilai kepada bagian layanan Registrasi Perkuliahan dan Ujian (RPU) dan lamanya proses hasil nilai yang ditampilkan sistem penilaian hasil belajar dan ujian mahasiswa pada perguruan tinggi, merupakan suatu sistem pelayanan yang mutlak dibutuhkan bagi dosen maupun manajemen perguruan tinggi, hasil dari pengolahan tersebut berupa Kartu Hasil Study (KHS), dan daftar nilai yang akan muncul pada sistem informasi Student Information System (SIS).

Dari pembahasan diatas, dapat dirumuskan satu permasalahan yaitu sebagai berikut :

Apakah sistem penilaian terkomputerisasi dapat membantu dosen agar lebih cepat dan efektif dalam penginputan nilai dan dapat mengembangkan mutu kualitas sistem pelayanan perguruan tinggi untuk manajemen, dosen, maupun mahasiswa perguruan tinggi ?

\section{TINJAUAN PUSTAKA}

\section{Definisi Yii Framework}

Dikutip dalam Wikipedia, Yii adalah framework (kerangka kerja) PHP berbasiskomponen, berkinerja tinggi untuk pengembangan aplikasi Web berskala-besar. Yii menyediakan reusability maksimum dalam pemrograman Web dan mampu meningkatkan kecepatan pengembangan secara signifikan. framework pemrograman umum Web yang bisa dipakai untuk mengembangkan semua jenis aplikasi Web. Dikarenakan sangat ringan dan dilengkapi dengan mekanisme caching yang canggih, Yii sangat cocok untuk pengembangan aplikasi dengan lalu lintas-tinggi, seperti portal, forum, sistem manajemen konten (CMS), sistem 
e-commerce, dan lain-lain.Yii melampaui framework PHP lain dalam hal efisiensi, kekayaanfitur, dan kejelasan dokumentasi. Yii didesain dengan hati-hati dari awal agar sesuai untuk pengembangan aplikasi Web secara serius. Yii bukan berasal dari produk pada beberapa proyek maupun konglomerasi pekerjaan pihak-ketiga. Yii adalah hasil dari pengalaman kaya para pembuat pada pengembangan aplikasi Web dan investigasi framework pemrograman Web dan aplikasi yang paling populer.

\section{Definisi Business Intelligence}

Pendapat Marry (2013) yang dikutip dari website scholar.google.id, Intelligence bisnis adalah kategori yang luas dari aplikasi dan teknologi untuk mengumpulkan, menyediakan akses dan menganalisis data untuk membantu perusahaan pengguna mengaktifkan keputusan bisnis yang optimal baik Business Intelligence (BI) adalah sekitar mendapatkan informasi yang tepat. Keputusan dinamis pembuatan secara efektif ditangani melalui pendekatan naluriah, dan membutuhkan justru berdasarkan metodologi analitis dan model matematika.

\section{Definisi Internet}

Dikutip dari Wikipedia, internet adalah singkatan dari kata Interconnection-Networking, yang memiliki arti seluruh jaringan komputer yang menggunakan standar sistem global Transmission Control Protocol/Internet Protocol (TCP/IP) yang saling terhubung sebagai protokol pertukaran paket (packet switching communication protocol) untuk melayani miliaran pengguna di seluruh dunia.

Pendapat dari Munir (2009) dalam buku Yakub dan Vico (2014:137), internet adalah media berinteraksi serta berbagi informasi kapan serta di mana saja.

Berdasarkan kutipan di atas dapat disimpulkan internet adalah jaringan komputer yang terhubung dengan sistem global yang dapat menjadi sebuah media berimteraksi dan berbagi informasi antar pengguna di seluruh dunia.

\section{LITERATURE REVIEW}

Banyak penelitian yang sebelumnya dilakukan berkenaan dengan Literature Review mengenai konsep antara diskusi dengan teknologi. Dalam upaya mengembangkan $P E N+$ ini perlu dilakukan studi pustaka sebagai salah satu dari penerapan metode penelitian yang akan dilakukan. Diantaranya adalah mengidentifikasikan kesenjangan dan mengidentifikasikan metode yang pernah di lakukan, meneruskan penelitian sebelumnya, serta untuk mengetahui orang lain yang spesialisasi dan area penelitiannya sama di bidang ini. Beberapa Literature Review tersebut adalah sebagai berikut :

1. Penelitian ini dilakukan oleh Ary Budi Warsito, Muhamad Yusup, dan Yulianto pada tahun 2014, dengan judul "Kajian Yii Framework Dalam Pengembangan Website Perguruan Tinggi”. Membangun website Perguruan Tinggi Raharja menggunakan Yii Framework berbasis PHP dengan menggunakan metode MVC. Pengembangan sebuah website dengan menggunakan framework YII mudah dilakukan pada semua jenis aplikasi website serta sangat cocok untuk pengembangan aplikasi dengan lalu-lintas tinggi. Penulis mengadopsi untuk menggunakan YII Framework dalam mengembangkan formulir online karena mudah dilakukan dan cocok untuk pengembangan sistem.

2. Penelitian yang dilakukan oleh Erlita Rasdiana pada tahun 2013 dengan judul "Analisa pengembangan sistem System Information Student (SIS) pada perguruan tinggi Raharja" . Penelitian ini membahas tentang System Student Information Services (SIS) yang ada pada 
Perguruan Tinggi Raharja, SIS yang berjalan saat sudah cukup baik, namun sejalan dengan kemajuan dan perkembangan teknologi serta pengembangan kebutuhan Pribadi Raharja pada umumnya atas informasi mengenai segala bentuk pemberitahuan dan pengumuman secara umum maupun khusus, kedisiplinan dan layanan kepada mahasiswa, maka sistem ini memerlukan sistem yang benar-benar handal dan dapat berfungsi semaksimal mungkin untuk memberikan informasi serta memenuhi kebutuhan tersebut.

3. Penelitian ini dilakukan oleh Ary Budi Warsito, Muhamad Yusup, dan Iqbal Makaram pada tahun 2015, dengan judul "Perancangan SIS+ Menggunakan Metode YII Framework Pada Perguruan Tinggi Raharja". Perancangan suatu sistem informasi akademik SIS+ menggunakan Yii Framework yang sudah berbasis OOP (Object Oriented Programming) sehingga terstruktur dan mudah dikembangkan. Penulis mengadopsi konsep pembuatan sistem informasi menggunakan framework YII yang berbasis OOP.

4. Penelitian yang dilakukan oleh Susy Kusuma Wardani pada tahun 2013 yang berjudul "Sistem Informasi Pengolahan Data Nilai Siswa Berbasis Web Pada Sekolah Menengah Atas (SMA) Muhammadiyah Pacitan". Penelitian ini dilakukan dengan maksud dapat membantu menyajikan informasi pengolahan nilai, yang akurat dan relevan. Tidak hanya itu bahwa sistem ini juga dapat meningkatkan kinerja dalam rangka melakukan pelayanan dan penyelesaian tugas dengan baik sesuai dengan kebutuhan manajemen yang diterapkan oleh SMA Muhammadiyah Pacitan.

5. Penelitian yang dilakukan oleh Rahmawati pada tahun 2012 yang berjudul "Analisis Penerapan Sistem Informasi Akademik (Siakad) Online Di Universitas Sultan Ageng Tirtayasa". Penelitian ini dilakukan bukan hanya untuk mengukur penerapan SIAKAD Online, tetapi juga untuk mengukur kepuasan responden atas penerapan SIAKAD Online selama ini di UNTIRTA menurut mahasiswa dan juga dosen. Menurut Mahasiswa portal akademik atau SIAKAD Online sudah membantu mahasiswa untuk bisa melihat nilai matakuliah dari tempat tinggalnya, tanpa harus datang ke kampus. Disamping itu pula, SIAKAD Online memudahkan mahasiswa untuk melakukan kontrak perkuliahan dari jauh, meskipun kadang-kadang portal akademik sulit dibuka atau meskipun bisa dibuka biasanya loadingnya lama atau waktu untuk mengaksesnya lama. Demikian pula menurut dosen, bahwa penerapan SIAKAD Online sudah memudahkan dosen untuk dapat menginput nilai dimana saja, tidak harus di kampus.

6. Penelitian yang dilakukan Untung Rahardja, Khanna Tiara, Ray Indra Taufik Wijaya pada tahun 2014 dengan judul penelitian "Penerapan Rinfo Sebagai Media Pendukung Untuk Proses Pembelajaran Pada Perguruan Tinggi Raharja". Penelitian ini membahas mengenai inovasi yang telah diterapkan oleh Perguruan Tinggi Raharja, yaitu dengan digunakannya metode iLearning (Integrated Learning) dalam proses pembelajarannya. Dimana pembelajaran tersebut sudah berbasis online. Metode iLearning ini terdiri dari TPi (Ten Pilar IT iLearning) atau 10 pilar IT iLearning. Rinfo adalah salah satu dari sepuluh pilar tersebut, dimana Rinfo ini menjadi email resmi yang digunakan oleh seluruh civitas yang ada di Perguruan Tinggi Raharja untuk saling berkomunikasi. Rinfo ini adalah Gmail, yang di adaptasi dari Google Platform dengan ciri khas raharja.info sebagai domainnya. Rinfo ini adalah media komunikai sekaligus alat pendukung dalam proses pembelajaran di Perguruan Tinggi Raharja. Karena selain terintegrasi dengan TPi, Rinfo ini pun terhubung pula dengan alat penunjang pembelajaran lainnya, seperti Docs, Drive, Sites, dan alat penunjang lainnya.

7. Penelitian yang dilakukan oleh Budiman pada tahun 2011 dengan judul "Pengembangan Aplikasi Rapor Online Berbasis Web Studi Kasus Madrasah Aliyah Negeri 4 Jakarta". 
Penelitian ini menggunakan tahapan-tahapan dari pengembangan sDLC dengan model proses waterfall. Bahasa pemrograman yang digunakan adalah PHP dan database yang digunakan adalah MySQL. Dengan adanya aplikasi rapor berbasis web ini memberikan kemudahan dalam mengakses aplikasi sehingga memudahkan guru dan siswa untuk menggunakannya.

8. Penelitian yang dilakukan oleh Chandra Tri Harianto pada tahun 2011 dengan judul sitem Informasi Pengolahan Nilai Pada Sekolah Menengah Penelitian ini menggunakan metode observasi dan wawancara dengan menggunakan teknik pengumpulan data primer dan sekunder. Program yang dikembangkan menggunakan PHP berbasis orientasi dan MySOL dengan Codeigniter. Aplikasi yang dihasilkan berbasis web sehingga dapat dijalankan menggunakan fasilitas browser dan local server Adapula fasilitas tambahan adalah fasilitas untuk admin yang berguna mengelola pengguna yang memberi level kepada pengguna. Selain itu, terdapat fasilitas untuk merubah sandi pada masing pengguna.

9. Penelitian yang dilakukan oleh Dhani Eka Friha tara pada tahun 2013 dengan judul "Analisis dan Perancangan Program Evaluasi Hasil Bel Peneliti Siswa Berbasis Web Di SD Negeri Gari 1 Gunungkidul". Penelitian ini menggunakan metode perancaangan sistem menggunakan Flowchart dan DFD Diagram, script yang menggunakan PHP dan web server xampp. Dengan adanya sistem ini dapat memenuhi keutuhan para guru dalam pembuatan laporan program evaluasi belajar siswa dan meningkatkan mutu pendidikan sekolah.

10. Penelitian yang dilakukan oleh Susy Kusumaa Wardani pada tahun 2013 dengan judul "Sistem Informasi Pengolahan Data Nilai siswa Berbasis Web Pada Sekolah Menengah Atas (SMA) Muhammadiyah Pacitan". Penelitian ini bertujuan untuk membangun suatu sistem informasi mempermudah pengecekan, pencatatan dan laporan data nilai siswa yang terkomputerisasi. Aplikasi ini menggunakan multi user terdiri admin pada bagian login saat akan membuka aplikasi sehingga keamanan program ada. Sistem ini bekerja memasukan dan menyimpan laporan nilai serta menampilkan info dari sekolah tersebut sehingga lebih mudah mengetahui informasi yang akan disampaikan oleh pihak sekolah. Penelitian ini telah menghasilkan sebuah sistem pengolahan nilai yang membantu kerja dari para guru dan wali kelas dan dapat mempermudah pengguna untuk melakukan proses pengolahan nilai agar pengelolaan nilai dapat di olah secara efektif dan efisien, sehingga bisa langsung di akses serta informasi (pengumuman) dapat tersampaikan dengan baik.

Dari sepuluh literature review yang ada, telah banyak penelitian mengenai metode pembelajaran menggunakan media forum atau yang lainnya. Itulah alasan mengapa penulisan ini membahas hal tersebut. Agar nanti bisa dijadikan acuan sebagai referensi oleh dosen maupun mahasiswa

\section{PEMBAHASAN}

Untuk mengatasi berbagai masalah seperti yang dijelaskan diatas, dapat dilakukan dengan cara menggunakan aplikasi yang memudahkan proses penilaian dengan menggunakan sistem $P E N+$, maka diperlukan proses yang cepat dan efisien agar dapat menyelesaikan masalah yang terjadi diatas. Saat ini proses penilaian masih terkomputerisasi namun belum online, Dosen dapat melakukan pengoreksian nilai UTS,UAS dan TM lebih mudah dan tidak ada monitoring untuk hal ini, belum lagi proses yang panjang untuk penilaian saja. Sistem PEN+ dapat membantu dosen agar lebih cepat dalam penginputan nilai dan melakukan penginputan dengan 
mudah. Sistem PEN+ bukan hanya sekedar untuk monitoring dosen dalam penginputan nilai, tetapi juga dalam hal gamifikasi dosen dan kecepatan informasi yang diterima oleh mahasiswa.

Pada sistem penilaian sebelum PEN+ harus dilakukan oleh staf RPU yang menginput hasil penilain mahasiswa per mata kuliah dari 41 dosen dengan 180 kelas, staf RPU hanya terdapat 5 staf dan harus menginput nilai 180 kelas dari tiap mata kuliahnya dan per-mata kuliahnya terdapat 25 sampai 50 mahasiswa didalam kelas, sehingga penginputan nilai menjadi lambat dan sangat tidak efektif. Berbeda dengan sistem $P E N+$, pada sistem $P E N+$ sudah memiliki beberapa fitur pendukung pada saat penginputan nilai. Fitur ini juga sangat membantu dan menunjang kegiatan pada saat penginputan nilai, dan agar dosen lebih mudah untuk penginputan nilai, $P E N+$ bersifat online dan dapat digunakan dimana saja dengan menggunakan device apapun. Semua Pribadi Raharja bisa menggunakan PEN+. Jika semua Pribadi raharja dapat menggunakan sistem $P E N+$ ini tentu saja yang akan menguntungkan dosen dan mahasiswa dalam informasi penilaian, dan pasti lebih meningkatkan kecepatan nilai informasi hasil ujian tersebut.

Tentu saja semua Pribadi Raharja bisa menggunakan PEN+ tersebut, sistem ini mempunyai fasilitas berupa Viewboard, Viewboard All Kelas, Login History, Data Perubahan Nilai, Gamification, Grafik, Log Pages sis+, dan Rank Pages SIS+, Mahasiswa Get Nilai, Testimoni, FAQ?, saran dan Kritik. Juga dapat diakses untuk kepentingan pada saat menjalankan aktivitas pada saat penilaian ujian. Dan berikut ini adalah gambaran skema dari antara dosen dan mahasiswa dengan teknologi yang akan digabungkan dan dihubungkan menjadi sebuah metode Penilaian online, yang akan memudahkan arus perkembangan pada saat akan menyampaikan hasil kepada mahasiswa dengan menggunakan teknologi Sistem PEN+. Supaya dalam skema yang akan dibuat, nantinya akan dilakukan oleh penilaian oleh dosen pada saat penilaian. 
ISSN: 2461-1409

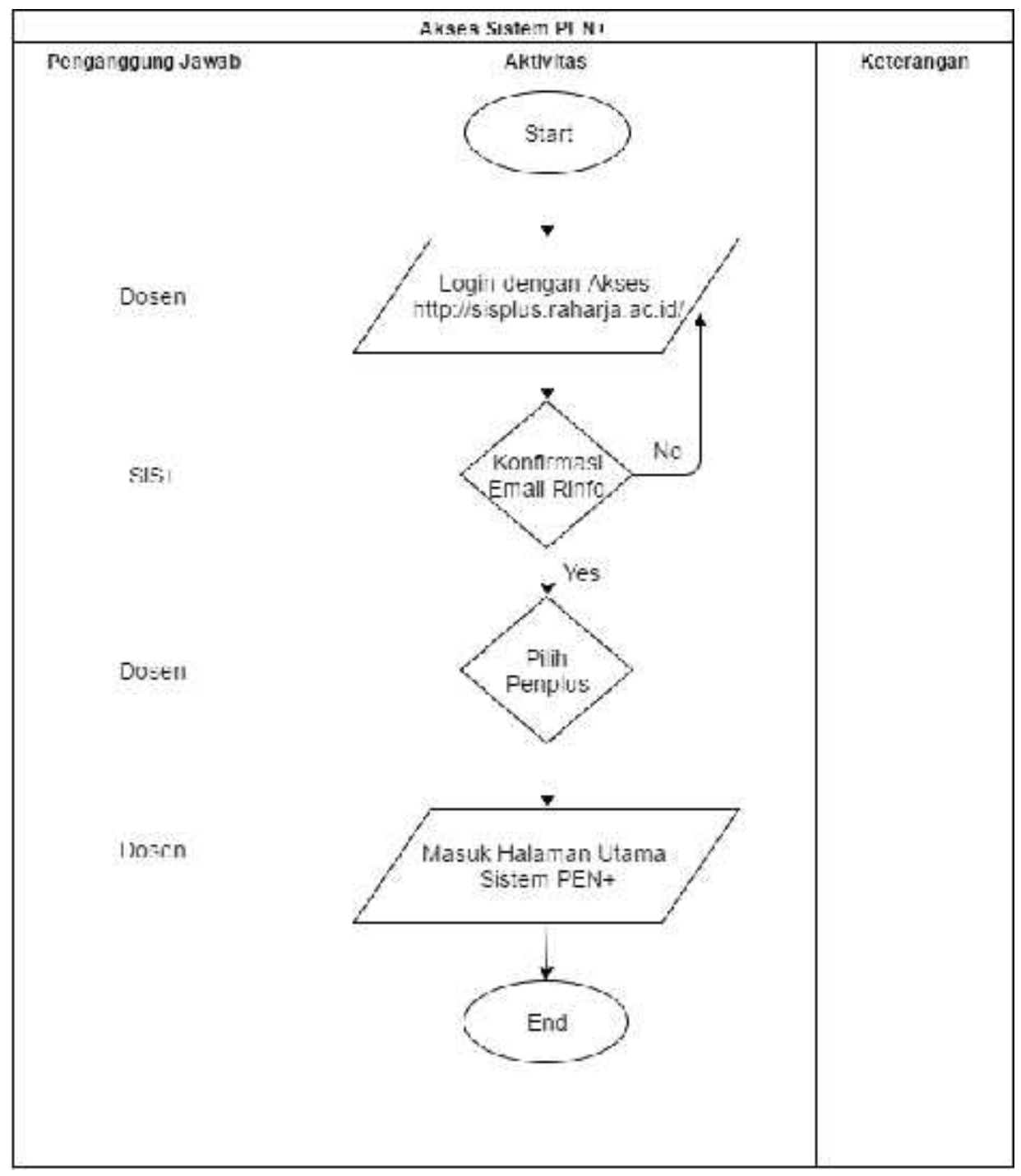

Flowchart 1. Flowchart akses PEN+

Gambar di atas menjabarkan proses akses PEN+. Langkah pertama adalah mengunjungi halaman http://sisplus.raharja.ac.id. Lalu pilih konfirmasi yes. Kemudian pilih PEN+ lalu dosen akan masuk kehalaman utama sistem PEN+. 


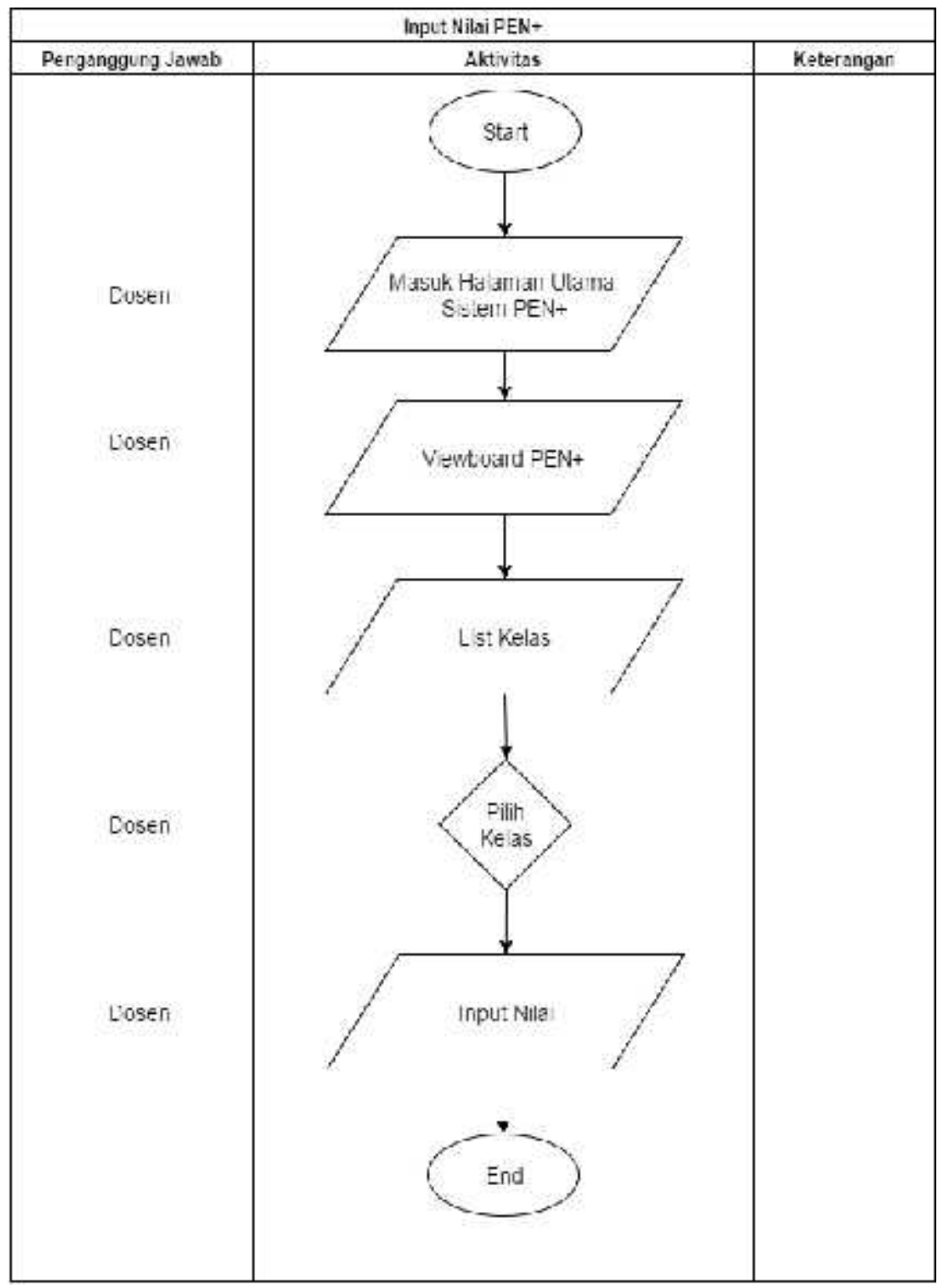

\section{Flowchart 2. Flowchart proses Input Nilai PEN+}

Gambar di atas menjabarkan proses input nilai PEN+. Dimulai dari mengunjungi halaman_utama sistem PEN+. Lalu mengunjungi viewboard PEN+, lalu memilih List Kelas dan pilih kelas lalu kemudian Menginput nilai . 


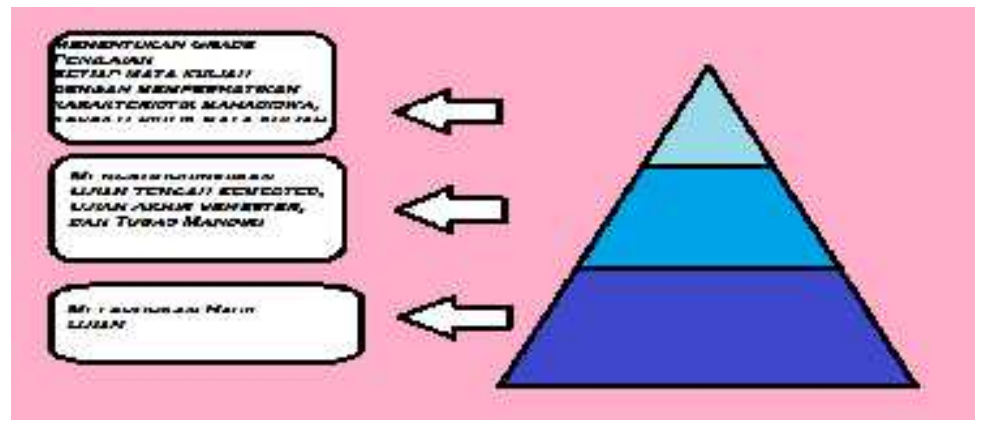

Figure 1. Skema dari aktivitas proses pembelajaran.

Pada gambar diatas adalah figure dimana lingkaran menunjukkan terdapat tiga aktivitas dalam penilaian yaitu Menentukan Grade Penilaian setiap mata kuliah dengan memperhatikan karakteristik mahasiswa, karakteristik mata kuliah, dan kondisi satuan pendidikan melalui rapat dewan pendidik. (1) Mengkoordinisikan dalam Ujian Tengah Semester, Ujian Akhir Semester, dan Tugas Mandiri. (2) melaporkan Hasil Ujian. (3)

UTS

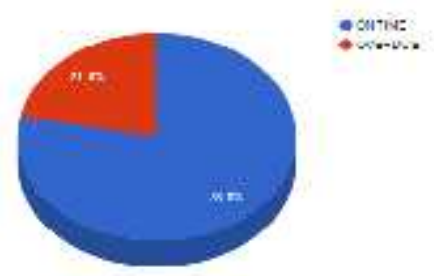

Diagram 1. Statistik pada saat penginputan UTS.

Grafik diatas menunjukan adanya penilaian dosen sistem PEN+. Dosen telah menginput nilai pada saat periode UTS dan $78.1 \%$ yang tersubmit secara Ontime, dan $21.9 \%$ dosen yang menginput lebih dari waktu yang ditentukan Overdue. Ini menunjukan bahwa sistem PEN+ memang sudah di terapkan pada Penilaian dosen maupun mahasiswa pada Perguruan Tinggi Raharja. Pada Progress Binaan Kajur, jurusan yang di kepalai oleh Ibu Euis mendapatkan peringkat tinggi pada Progress Binaan Kajur di sistem PEN+.

Adapun proses dosen di sistem PEN+ sebagai berikut: 


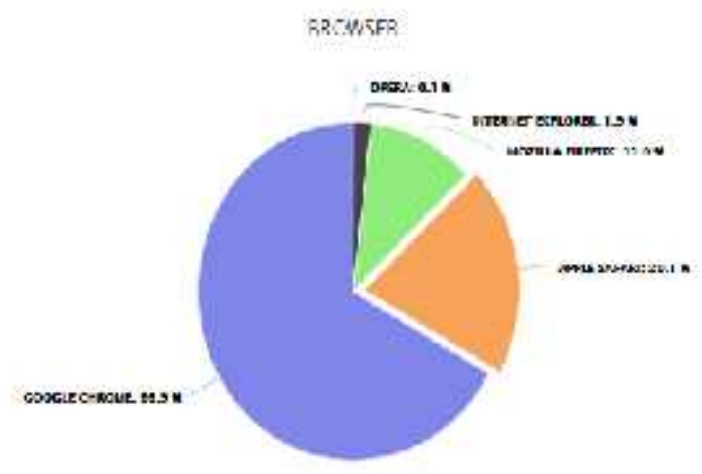

\section{Gambar 2. Rangking pada Login History}

Pada gambar 2. tersebut adalah suatu Rangking pada Login History Dosen dan Mahasiswa yang dilakukan pada saat proses penilaian Ujian Akhir Semester (UAS), Ujian Tengah Semester (UTS), dan Tugas Mandiri (TM). Disini terdapat monitoring terhadap dosen yang tepat waktu dalam penginputan nilai. Dimana dalam sistem PEN+ ini terdapat pula gamification untuk dosen dan para binaan kepala jurusan untuk menduduki rating paling tertinggi dan tidak overdue.

Kelebihan dari sistem PEN+ sangat berbeda dengan sistem penilaian yang lain. Karena sistem ini mempunyai beberapa ciri khas yang menjadi unggulan untuk meningkatkan proses penilaian, dan karena itu ciri khas juga dijadikan sebagai mayoritas utama untuk berkembangnya kemajuan teknologi semakin canggih dan modern. Dengan PEN+ ini, dosen dan mahasiswa dapat saling berkembang di Perguruan Tinggi. Sehingga penilaian pun lebih efektif, efisien dan menyenangkan sesuai konsep Penilaian .Dari 10 (sepuluh) kelebihan, ada 3 (tiga) yang akan ditampilkan, antara lain :

1. PEN+ merupakan sebuah sistem dengan menggunakan metode Online. Kenapa Online ?, Karena perkembangan dunia IT semakin meningkat, demi mengikuti arus zaman yang canggih dalam metode penilaian saat ini.

2. PEN+ menjadi sangat istimewa karena hal-hal yang mudah dipahami dan Log in yang sudah Single Sign Out (SSO) Rinfo.

3. $P E N+$ juga menampilan informasi tentang nilai mahasiswa,dan perkembangan mutu kualitas dosen serta mahasiswa.

dari 3 (tiga) kelebihan yang dijelaskan dari 10 (sepuluh) kelebihan diatas PEN+ tersebut, $P E N+$ mempunyai perbedaan dengan sistem penilaian lain. Karena sistem PEN+ ini memang lebih efektif untuk dosen dan mahasiswa pada Perguruan Tinggi.

PEN+ masih mempunyai kekurangan diataranya Ruang lingkup hanya Perguruan Tinggi, tidak bisa digunakan dari luar melainkan hanya untuk dosen dan mahasiswa Perguruan Tinggi Raharja. Yang bukan berasal dari Perguruan Tinggi Raharja tidak dapat melihat sistemnya. 5 (Lima) kegunaan dari $P E N+$, antara lain :

1. Penilaian dapat dilakukan dimana saja dan menggunakan segala macam device apapun

2. Individualisasi penerima informasi: tanggapan pribadi di sistem PEN+ cepat akses dan tidak membutuhkan waktu lama. Mahasiswa maupun dosen memiliki kebebasan untuk mengetahui hasil ujian.

3. Mendorong bekerja dengan aktif dan cepat: Sistem PEN+ yang efektif, terbuka dan dirancang untuk mendorong Mutu Perguruan Tinggi. 
4. Otonomi Pribadi Raharja: Civitas Pribadi Raharja memiliki fleksibilitas untuk merefleksikan pikiran mereka dan membaca tanggapan.

5. Lebih banyak kegunaan dan lebih praktis dalam penilaian maupun proses penilaian serta cepat update untuk informasi penilaian.

\section{IMPLEMENTASI}

Tampilan website sistem PEN+ yang memiliki berbagai macam fitur yang dapat digunakan oleh mahasiswa maupun dosen yang terdiri dari:

- Halaman Utama

forum tersebut dapat diakses di luar kampus oleh dosen maupun mahasiswa dengan menuju alamat website http://sisplus.raharja.ac.id.

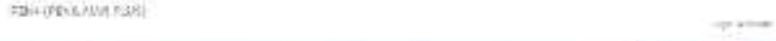

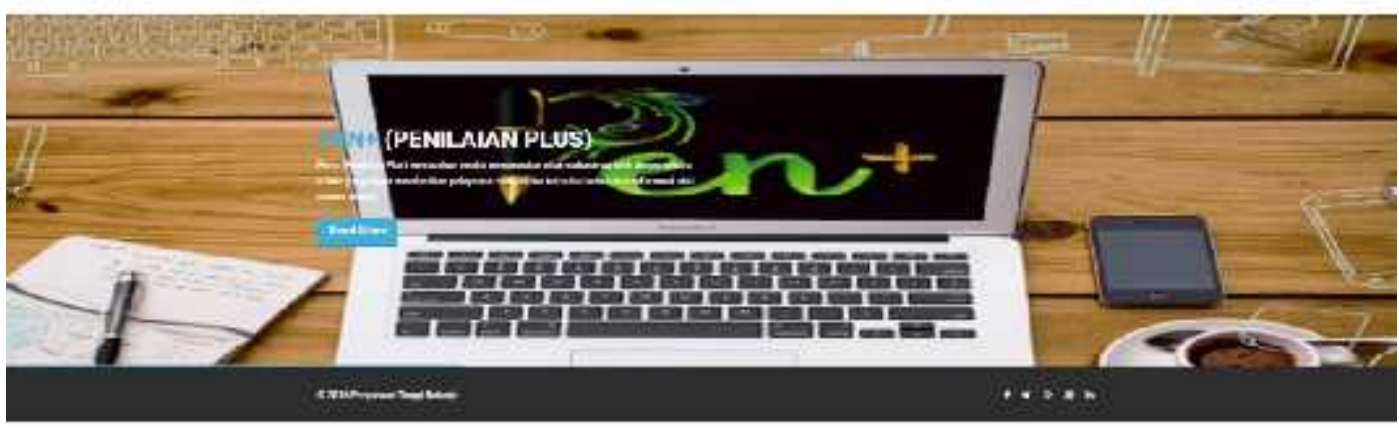

Gambar 3. Login pada sistem PEN+

Seperti sistem lainnya adanya login untuk masuk ke dalam website sistem agar dapat mengakses dan menginput nilai kedalam sistem PEN+ dengan menggunakan Sisplus atau Akun Rinfo .

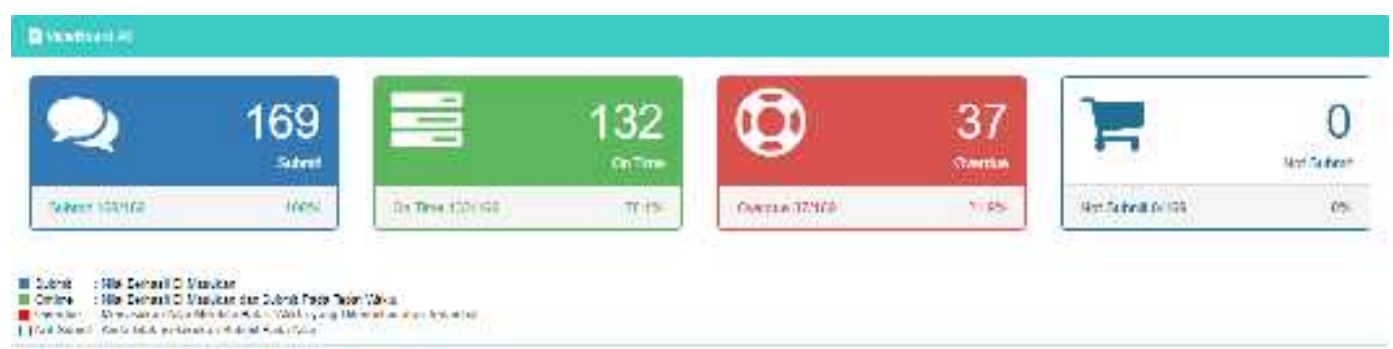

Gambar 4. Viewboard All Pada Sistem PEN+

- Adanya Viewboard untuk melihat jumlah kelas yang sudah (Submit), dan dosen yang submit dengan tepat waktu (On Time), adapun dosen yang menginputkan nilai melewati batas waktu (Overdue) atau berapa kelas dari dosen yang belum submit (Not Submit). 


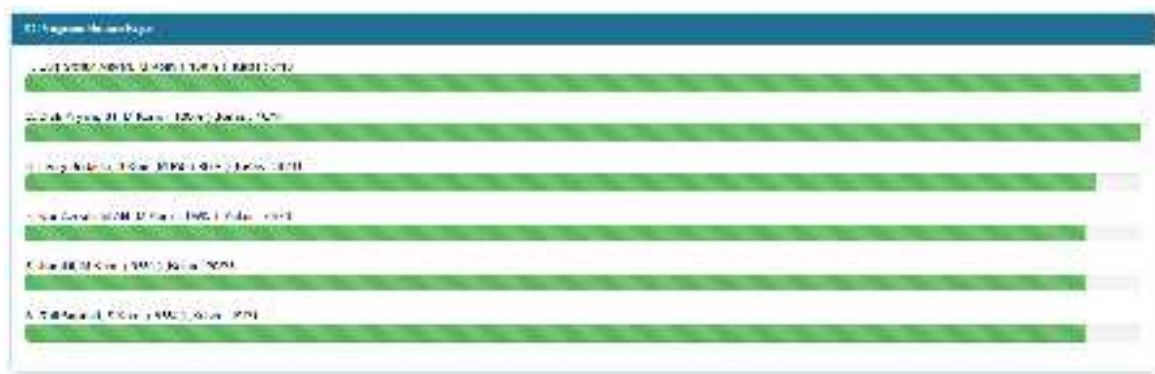

Gambar 5. Gambar Progress Binaan Kajur

List diatas menunjukan adanya penilaian dosen dalam setiap jurusan pada sistem PEN+. Ini menunjukan bahwa sistem PEN+ memang sudah di terapkan pada Penilaian dosen maupun mahasiswa pada Perguruan Tinggi Raharja. Pada Progress Binaan Kajur, jurusan yang di kepalai oleh Ibu Euis mendapatkan peringkat tinggi pada Progress Binaan Kajur di sistem PEN+.

Adapun proses dosen di sistem PEN+ sebagai berikut :

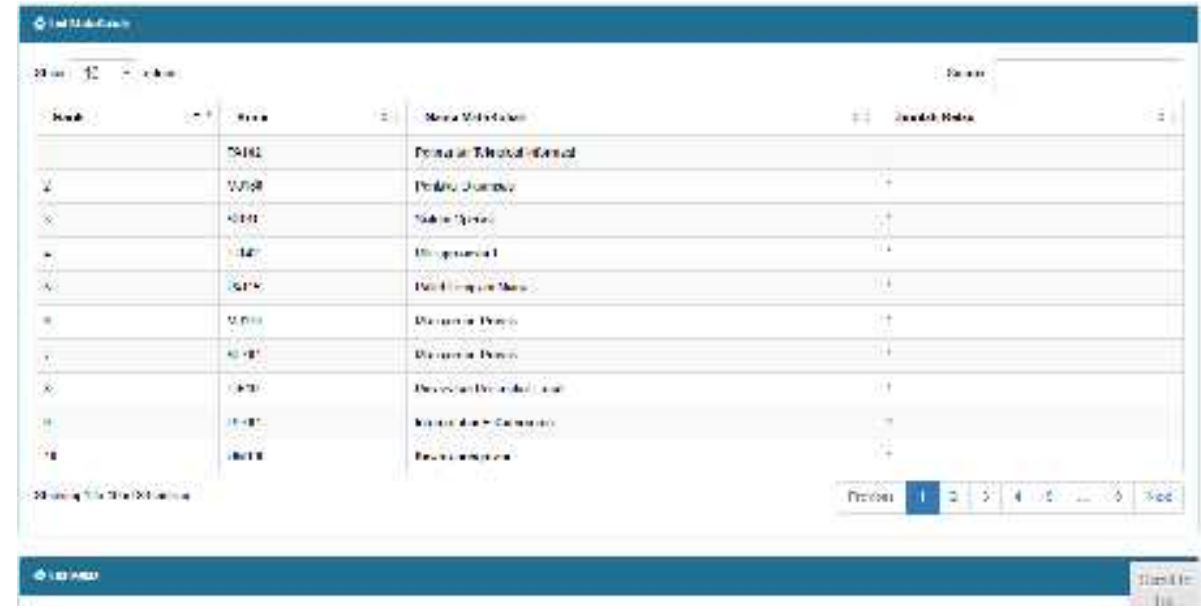

Gambar 6. List Matakuliah

- Adanya fasilitas kegiatan penginputan nilai per-mata kuliah yang diisi oleh dosen yang terkait didalam List Mata Kuliah. Media PEN+ sebagai pengembangan mutu pelayanan manajemen dosen maupun mahasiswa di Perguruan tinggi dinilai sangat efektif sekali. 


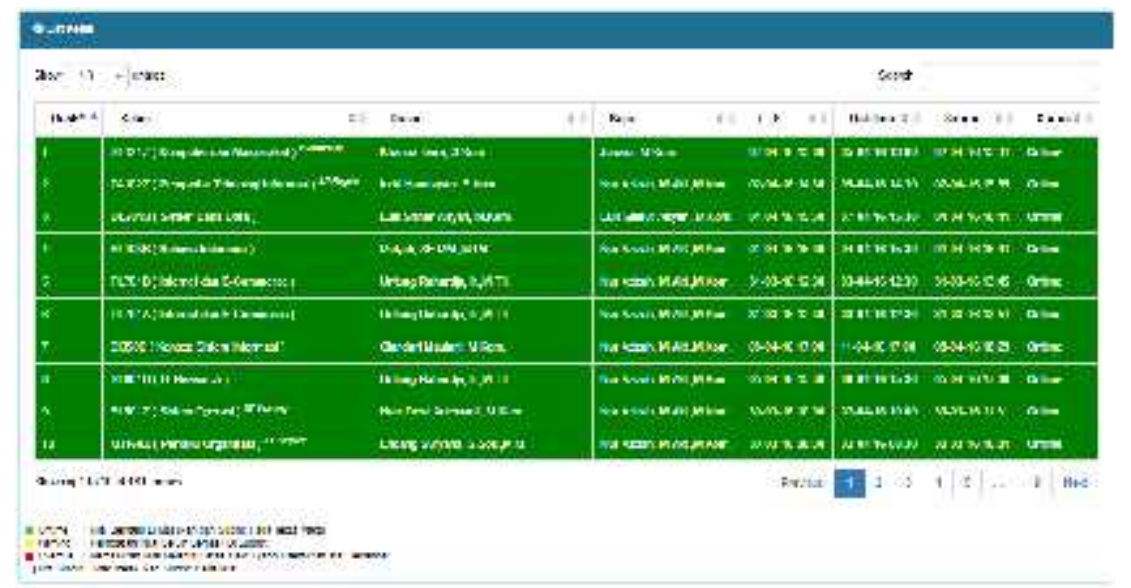

\section{Gambar 7. List Kelas}

- Adanya fasilitas List Kelas yang menjadi gamifikasi para dosen untuk lebih mengejar ketepatan waktu dalam saat penginputan nilai hasil ujian para mahasiswa.

\section{KESIMPULAN}

Dengan demikian dapat disimpulkan bahwa PEN+ dapat membantu dosen dan mahasiswa untuk menginput nilai dan mengetahui nilai dengan cepat, ini dikarenakan mahasiswa berhak melihat nilai sesuai batas waktu yang ditentukan untuk dosen menginput nilai ujian, yaitu $\mathrm{H}+3$ setelah ujian berlangsung. Dengan PEN+ mahasiswa dapat langsung mengetahui nilai karena setelah dosen selesai menginputkan nilai hasil ujian akan terdapat notifikasi kepada seluruh mahasiswa didalam kelas tersebut. PEN+ di Perguruan Tinggi Raharja akan dapat mendukung proses pembangunan mutu kualitas pelayanan manajemen dosen dan mahasiswa pada perguruan tinggi yang ada, khususnya civitas yang online yang sudah diterapkan di Perguruan Tinggi Raharja. Dilihat dari segi keamanannya sudah baik, yang juga terintegrasi dengan baik yang hanya bisa diakses menggunakan akun Rinfo. Kemudian, banyak tools di $P E N+$ yang dapat mendukung proses penilaian. Terdapat fasilitas, yang memudahkan untuk meninput nilai dan dokumen yang tidak akan rusak. sehingga mahasiswa atau dosen lebih mudah untuk mengakses nilai tidak perlu ngetik URL akan tetapi cukup dengan mengunjungi sisplus.raharja.ac.id. Terdapat Fasilitas yang membantu dosen agar lebih mudah untuk penginputan nilai dan melihat rating keaktifan dosen saat penginputa nilai . Terdapat sistem notifikasi yang langsung terkirim melalui Rinfo saat dosen selesai mensubmit nilai sehingga nilai lebih cepat terupdate dan tidak membutuhkan waktu yang lama . Setiap pengguna sistem PEN+ cukup mudah dan cepat memahami cara-cara penggunaan PEN+. Hanya dengan mengunjungi sisplus.raharja.ac.id dengan menggunakan email Rinfo mahasiswa atau dosen sudah memiliki akun $P E N+$. Dengan PEN+ segalanya menjadi mudah dan penilaian menjadi menyenangkan . 


\section{DAFTAR PUSTAKA}

[1] Warsito, Ary Budi, Muhamad Yusup, Yulianto (2014) "Kajian Yii Framework Dalam Pengembangan Website Perguruan Tinggi”. Jurnal CCIT Vol.7 No.3 Mei 2014. ISSN: 1978 - 8282. Tangerang : Perguruan Tinggi Raharja.

[2] Rasdiana, Erlita (2013) "Analisa pengembangan sistem System Information Student (SIS) pada perguruan tinggi Raharja". Tangerang : Perguruan Tinggi Raharja.

[3] Warsito, Ary Budi, Muhamad Yusup, Iqbal Makaram. (2015) "Perancangan SIS+ Menggunakan Metode YII Framework Pada Perguruan Tinggi Raharja". Jurnal CCIT Vol.8 No.2. Tangerang : Perguruan Tinggi Raharja.

[4] Wardani, Susy Kusuma (2013) "Sistem Informasi Pengolahan Data Nilai Siswa Berbasis Web Pada Sekolah Menengah Atas (SMA) Muhammadiyah Pacitan. IJNS-Indonesian Journal on Networking and Security Vol. 2 No. 2.

[5] Rahmawati (2012) "Analisis Penerapan Sistem Informasi Akademik (SIAKAD) Online di Universitas Sultan Ageng Tirtayasa”. JAP 3, No. 1.

[6] Rahardja, Untung, Dkk (2014) "Penerapan Rinfo Sebagai Media Pendukung”. Jurnal CCIT Vol.8 No.1 September 2014. ISSN: 1978-8282. Tangerang : Perguruan Tinggi Raharja.

[7] Budiman (2011) "Pengembangan Aplikasi Rapor Online Berbasis Web Studi Kasus Madrasah Aliyah Negeri 4 Jakarta". JAP 3, No. 1.

[8] Harianto, Chandra Tri (2011) "sitem Informasi Pengolahan Nilai Pada Sekolah Menengah".

[9] Friha, Dhani Eka, (2013) "Analisis dan Perancangan Program Evaluasi Hasil Bel Peneliti Siswa Berbasis Web Di SD Negeri Gari 1 Gunungkidul". Jurnal KNSI. 2013. SD Negeri Gari 1.

[10] Wardani, Susy Kusuma (2013) "Sistem Informasi Pengolahan Data Nilai Siswa Berbasis Web Pada Sekolah Menengah Atas (SMA) Muhammadiyah Pacitan. IJNS-Indonesian Journal on Networking and Security Vol. 2 No. 2.

[11] Wahyani, Sri (2015) "Penerapan Online Jadwal Rencana Studi Plus (OJRS+) Untuk Kebutuhan Registrasi Perkuliahan Pada Perguruan Tinggi”. Tangerang : Perguruan Tinggi Raharja. 